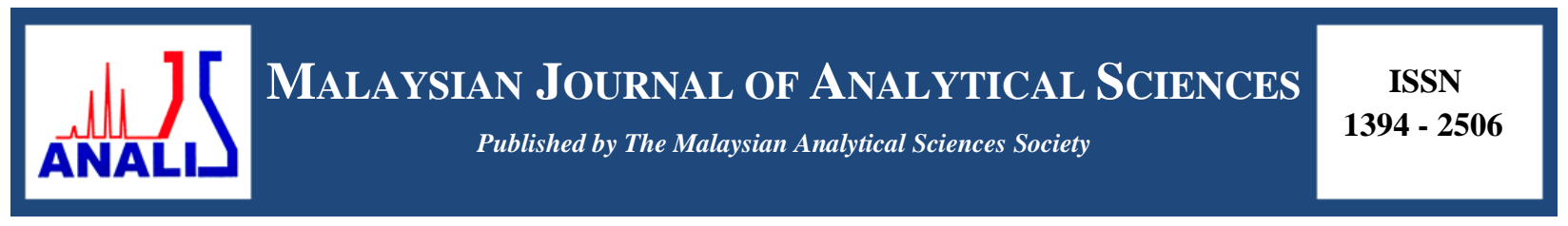

\title{
THE EFFECTS OF FE-DOPING ON MECHANICAL PROPERTIES IN $\mathrm{Bi}_{1.6} \mathrm{~Pb}_{0.4} \mathrm{Sr}_{2} \mathrm{Ca}_{2} \mathrm{Cu}_{3-X} \mathrm{Fe}_{X} \mathrm{O}_{Y}$ SUPERCONDUCTOR
}

\author{
(Kesan Dop Ferum Terhadap Sifat Superkonduktor $\mathrm{Bi}_{1.6} \mathrm{~Pb}_{0.4} \mathrm{Sr}_{2} \mathrm{Ca}_{2} \mathrm{Cu}_{3-x} \mathrm{Fe}_{x} \mathrm{O}_{y}$ ) \\ Suazlina Mat Ali ${ }^{1}$, Azhan Hashim ${ }^{2}$, Syamsyir Akmal Senawi ${ }^{2}$, Azman Kasim $^{2}$, Wan Aizuddin Wan Razali ${ }^{2}$, \\ Ruziana Mohamed ${ }^{2}$, Fairuzdzah Ahmad Lothfy ${ }^{2}$ \\ ${ }^{I}$ Faculty of Applied Sciences, \\ Universiti Teknologi MARA Shah Alam, 40450 Shah Alam, Selangor, Malaysia \\ ${ }^{2}$ Faculty of Applied Sciences, \\ Universiti Teknologi MARA Pahang, 26400 Bandar Jengka, Pahang, Malaysia \\ *Corresponding author: dazhan@pahang.uitm.edu.my
}

Received: 4 December 2016; Accepted: 1 December 2017

\begin{abstract}
Bi-2223 superconductors doped with $\mathrm{Fe}_{2} \mathrm{O}_{3}$ at $\mathrm{Cu}$-site were prepared in bulk form using high purity oxide powders via solid state reaction technique with intermediate grinding. The series of Fe stoichiometric ratio $(x=0.00,0.02,0.04,0.06,0.08$ and 0.10$)$ are systematically added to $\mathrm{Bi}_{1.6} \mathrm{~Pb}_{0.4} \mathrm{Sr}_{2} \mathrm{Ca}_{2} \mathrm{Cu}_{3-x} \mathrm{Fe}_{x} \mathrm{O}_{y}$ system to study the effect of $\mathrm{Fe}$ doping on mechanical and superconducting system properties. Vickers hardness, electrical resistivity, X-ray diffraction and Field Emission Scanning Electron Microscopy have been carried out to assess the effects of Fe doping. These measurements indicate that the Fe doping decreased the critical temperature and deteriorated formation of high $T_{c}$ phase, compared to undoped sample. Grain size of the samples were also reduced by increasing the amount of $\mathrm{Fe}$ and the mechanical properties were found to be escalate with the increasing of $\mathrm{Fe}$ concentration.
\end{abstract}

Keywords: BSCCO superconductor, Fe-doped, critical current density, X-ray diffraction, microhardness

\section{Abstrak}

Superkonduktor $\mathrm{Bi}-2223$ dop $\mathrm{Fe}_{2} \mathrm{O}_{3}$ dikawasan kuprum telah dihasilkan secara pukal menggunakan serbuk oksida tulin dengan kisaran perantara melalui kaedah tindak balas keadaan pepejal. Nisbah stokiometri bersiri $(x=0.00,0.02,0.04,0.06,0.08$ and 0.10) ditambah secara sistematik terhadap sistem $\mathrm{Bi}_{1.6} \mathrm{~Pb}_{0.4} \mathrm{Sr}_{2} \mathrm{Ca}_{2} \mathrm{Cu}_{3-x} \mathrm{Fe}_{x} \mathrm{O}_{y}$ bagi mengkaji kesan dop $\mathrm{Fe}$ terhadap sifat mekanikal dan sistem superkonduktor. Ujian ketahanan Vickers, kerintangan arus, pembelauan Sinar-X dan mikroskopi imbasan elektron pancaran medan telah dilakukan bagi menilai kesan dop Fe. Pencirian ini menunjukkan bahawa kesan dop yang dilakukan mengurangkan suhu genting dan merencatkan pembentukan fasa suhu tinggi berbanding sampel tanpa dop. Saiz butiran sampel turut mengecil dengan penambahan jumlah kehadiran Fe dan sifat mekanikal didapati meningkat seiring dengan penambahan Fe.

Kata kunci: Superkonduktor BSCCO, dop-Fe, ketumpatan arus, pembelauan sinar-X, ketahanan mikro

\section{Introduction}

Bi-Sr-Ca-Cu-O compound has been extensively studied since the discovery of high superconducting temperature [1]. This system has been investigated by many research groups concerning the preparation, superconducting properties, effect of doping as well as the structure of these compounds [2-6]. Among the BSCCO system, Bi-2223 is both fundamental and technological subject of interest because of its higher critical temperature, Tc [7]. The grain 


\section{Suazlina et al: THE EFFECTS OF FE-DOPING ON MECHANICAL PROPERTIES IN}

$\mathrm{Bi}_{1.6} \mathrm{~Pb}_{0.4} \mathrm{Sr}_{2} \mathrm{Ca}_{2} \mathrm{Cu}_{3-X} \mathrm{Fe}_{X} \mathrm{O}_{Y}$ SUPERCONDUCTOR

boundaries were essential as current transport factor in the polycrystalline form. Optimal sintering time is important to enhance the superconducting volume fraction and grains connectivity thus increases the critical sample current density. Short sintering time can produce smaller grain size, resulting in weak connectivity between grains. However, prolonging the sintering time may lead to phase decomposition, decreasing the superconducting phases and weakening the weak links. Bi-2223 is amenable for possible practical application as a conductor due to their large critical current density $[8,9]$.

However, it is difficult to obtain higher critical current density $J c$, which is significant for promising superconductor system. The selective substitution studies are essential and interesting for superconductivity research area in order to improve the critical current density. Elemental substitution is one of the important roles to enhance the $T_{c}$ and $J_{c}$ by improving the phase formation or microstructure of the system [10,11]. Practical applications, in terms of the BSCCO mechanical properties were also important for the studies since high temperature superconductors are generally restricted due to their brittleness in nature. The various substitutions have been investigated in order to improve the formation and stability of the 2223 phases and the most effective one is partial substitution of trivalent $\mathrm{Bi}$ with $\mathrm{Pb}$. The $3 \mathrm{~d}$ elements also embedded for substitution in $\mathrm{Bi}-2223$ system.

In this paper, the effect of $3 \mathrm{~d}$ elements $(\mathrm{Fe})$ that has been substituted into $\mathrm{Bi}(\mathrm{Pb})-2223$ superconductor through solid state reaction method was presented. The structural and transport properties of $\mathrm{Bi}_{1.6} \mathrm{~Pb}_{0.4} \mathrm{Sr}_{2} \mathrm{Ca}_{2} \mathrm{Cu}_{3-\mathrm{x}} \mathrm{Fe}_{\mathrm{x}} \mathrm{O}_{\mathrm{y}}$ were characterized using X-ray diffraction (XRD) and electrical resistivity measurement respectively while mechanical properties was unveiled using Vickers hardness.

\section{Materials and Methods}

The high- $T_{c}$ superconducting samples with nominal composition $\mathrm{Bi}_{1.6} \mathrm{~Pb}_{0.4} \mathrm{Sr}_{2} \mathrm{Ca}_{2} \mathrm{Cu}_{3-x} \mathrm{Fe}_{x} \mathrm{O}_{\mathrm{y}}$ (where $x=0.00,0.02$, 0.04, 0.06, 0.08 and 0.10) ceramic superconductor were prepared using the solid state reaction method. $\mathrm{The} \mathrm{Bi}_{2} \mathrm{O}_{3}$, $\mathrm{PbO}, \mathrm{SrCO}_{3}, \mathrm{CaCO}_{3}, \mathrm{Fe}_{2} \mathrm{O}_{3}$ and $\mathrm{CuO}$ powders with $99.9 \%$ purity were used. The powders were weighed according to their stoichiometry ratio. The powders were ball-milled together with absolute ethanol in alumina crucible for 24 hours. After that, the homogenous mixture of the powders was dried out in the oven at the $120{ }^{\circ} \mathrm{C}$ for 6 hours. The powders were ground and pre-calcined at $800{ }^{\circ} \mathrm{C}$ for 15 hours. Then the mixture of the powder was again calcined at $820^{\circ} \mathrm{C}$ for 15 hours to remove all oxides and carbonates. After that, the powders were pressed into pellet of 2 grams by applying a $30 \mathrm{MPa}$ pressure. Finally, the pellets were sintered at $850{ }^{\circ} \mathrm{C}$ for 48 hours to form a high- $T_{c}$ phase BSCCO superconductor. Results for $T_{c}, I_{c}$ and $J_{c}$ of the samples were measured by using four point probe machine. XRD analysis of the samples was carried out by using $\mathrm{Cu}\left(\mathrm{K}_{\mathrm{a}}\right)$ radiation. The surface morphologies of the samples were studies using FESEM machine, and the mechanical properties of the compounds have been investigated using Vickers hardness. All samples were denoted as sample $A, B, C, D, E$, and $F$ for $x=0.00,0.02$, $0.04,0.06,0.08$, and 0.10 respectively.

\section{Results and Discussion}

The normalized resistance at room temperature as a function of temperature between $30 \mathrm{~K}$ and $300 \mathrm{~K}$ with various concentration of $\mathrm{Fe}$ to Bi-2223 powder are shown in Figure 1. The curve indicated a metallic behaviour for all samples at normal state with a single leap of superconducting transition. The zero resistance temperature of the samples decreased with the addition of more dopant concentration into the system. Sample of Fe-doped with $x=$ 0.10 shows that there is no any transition to the superconducting state due to no $T_{c}$ zero. The highest $T_{c}$ zero was showed in pure sample is $93 \mathrm{~K}$ and decreases to $57 \mathrm{~K}$ for sample $x=0.08$.

Figure. 2 shows the XRD patterns of samples. All samples consisted of the Bi-2223 and Bi-2212 phase with the increasing of Bi-2212 phase induction. No peaks belongs to Fe were detected, which implied that the Fe had incorporated into the crystal structure subjected to the low amount of Fe. 


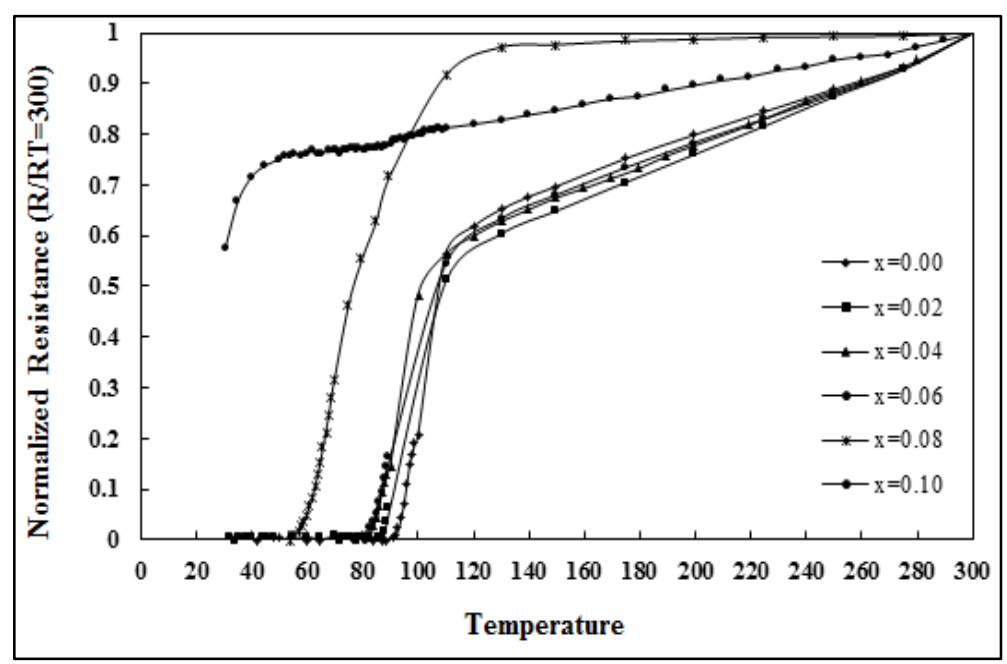

Figure 1. Normalized resistance as a function of temperature of the samples

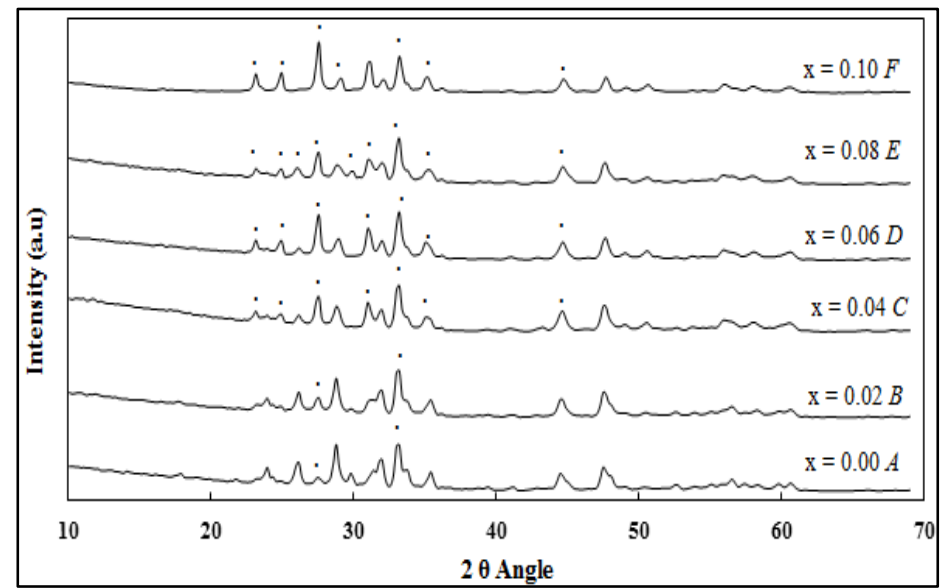

Figure 2. X-ray diffraction pattern of samples. The peaks indexed represent Bi-2212

Figure 3 shows the Vickers microhardness, Hv versus the concentration of $\mathrm{Fe}, x$ for all samples and the value of the Hv was tabulated in Table 1. It showed that the mechanical properties of the compounds were found to be linearly increased with the increasing of doping in Bi-2223 superconductors [12-15]. A sudden dropped was observed when $x=0.08$ and this behaviour is might be due to the contribution of weak grain boundaries in the sample. 
Suazlina et al: THE EFFECTS OF FE-DOPING ON MECHANICAL PROPERTIES IN

$\mathrm{Bi}_{1.6} \mathrm{~Pb}_{0.4} \mathrm{Sr}_{2} \mathrm{Ca}_{2} \mathrm{Cu}_{3-X} \mathrm{Fe}_{X} \mathrm{O}_{Y}$ SUPERCONDUCTOR

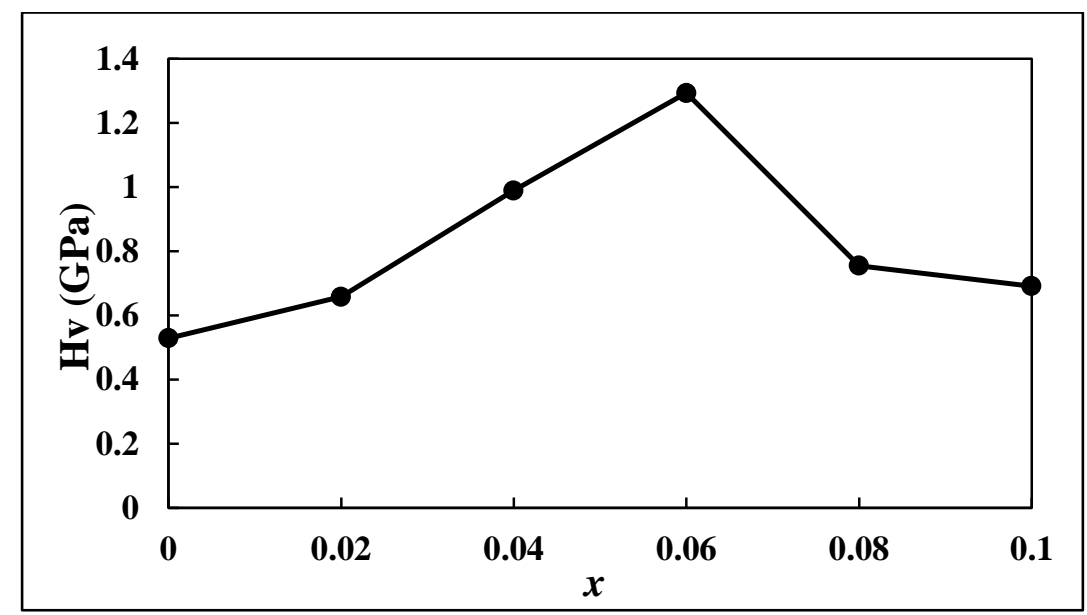

Figure 3. Vickers microhardness, $\mathrm{Hv}$ versus concentration of $\mathrm{Fe}, x$

Table 1. Critical temperature (Tc), critical current density $(J c)$, lattice parameter $a, b$ and $c$, volume fraction, and Vickers hardness (Hv) values for the samples

\begin{tabular}{lccccccc}
\hline Sample & $\begin{array}{c}\boldsymbol{T} \boldsymbol{c}_{\text {zero }} \\
(\mathbf{K})\end{array}$ & $\begin{array}{c}\boldsymbol{J}_{\boldsymbol{C}} \\
\left(\mathbf{A} / \mathbf{c m}^{2}\right)\end{array}$ & $\boldsymbol{\%} \mathbf{V}_{\mathbf{2 2 2 3}}$ & $\mathbf{a}$ & $\mathbf{b}$ & $\mathbf{c}$ & $\begin{array}{c}\mathbf{H v} \\
(\mathbf{G p a})\end{array}$ \\
\hline $\mathrm{A}$ & 93 & 4.8728 & 78.46 & 5.3891 & 5.4036 & 36.5143 & 0.529 \\
$\mathrm{~B}$ & 89 & 4.6180 & 75.06 & 5.3891 & 5.4036 & 36.5143 & 0.658 \\
$\mathrm{C}$ & 83 & 2.6225 & 66.13 & 5.3891 & 5.3434 & 33.9262 & 0.989 \\
$\mathrm{D}$ & 81 & 2.4026 & 29.64 & 5.3891 & 5.3582 & 33.8002 & 1.293 \\
$\mathrm{E}$ & 57 & 0.6197 & 24.48 & 5.3891 & 6.6780 & 30.6833 & 0.755 \\
F & - & - & 26.59 & 5.3891 & 5.5929 & 30.6201 & 0.691 \\
\hline
\end{tabular}

The FESEM micrographs of all samples in Figure 4 consisted of plate-like grains with randomly distributed as the typical grain structure of the high- $T_{c}$ phase (Bi-2223). It is observed that the grain connectivity is worsened greatly with increasing $\mathrm{Fe}$ concentration. The surface of the Fe-free sample is more uniform with better grains alignment. FESEM images of $x=0.00$ and $x=0.02$ show better crystallinity in comparison with the remaining two samples. Sample $x=0.10$ has the worst appearance among these six samples. These results indicate that the surface morphology of the sample is worsened with increasing of Fe substitution.
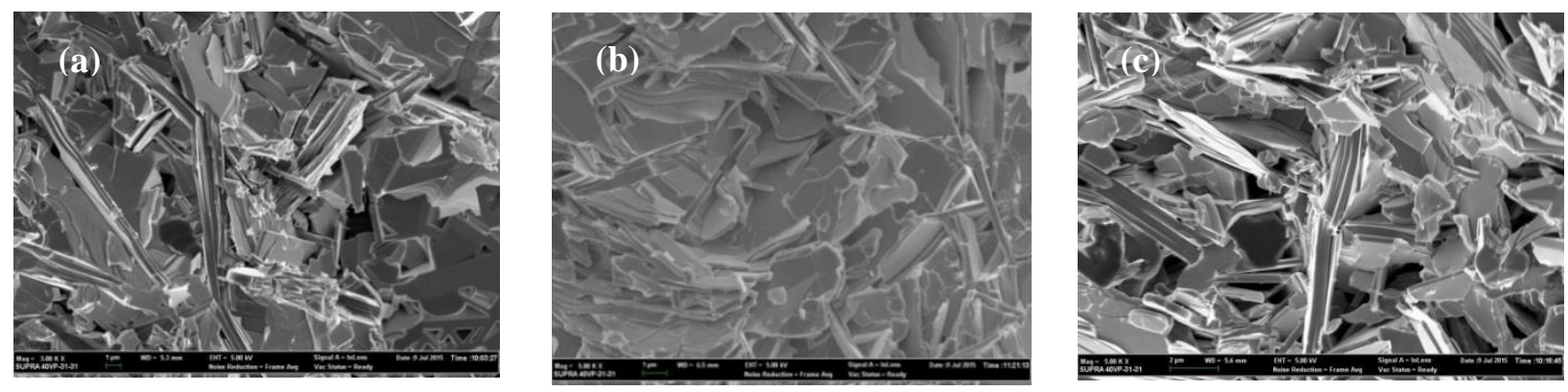

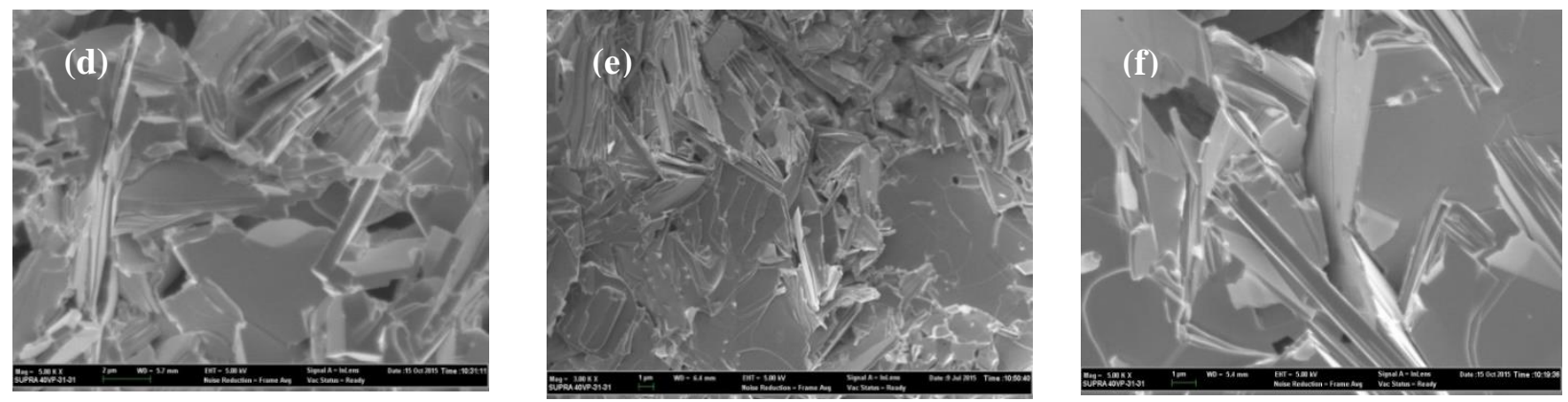

Figure 4. FESEM micrograph for the cross-section of the samples for a) $x=0.00, \mathrm{~b}) x=0.02, \mathrm{c}) x=0.04$, d) $x=0.06$, e) $x=0.08$ and f) $x=0.10$

\section{Conclusion}

The influence of $\mathrm{Fe}$ doping on mechanical properties in $\mathrm{Bi}_{1.6} \mathrm{~Pb}_{0.4} \mathrm{Sr}_{2} \mathrm{Ca}_{2} \mathrm{Cu}_{3-\mathrm{x}} \mathrm{Fe}_{\mathrm{x}} \mathrm{O}_{\mathrm{y}}$ system has been investigated. The results generally showed that the doping of Fe increased the mechanical properties of the samples until $x=$ 0.06 , and the value dropped when $x=0.08$. The doping of Fe also does not favour the formation of high $T c$ phase. The samples exhibit the decrease values of $T_{c}$ and $J_{c}$ after further addition of dopant concentrations. XRD analysis showed that the volume fraction of the 2223 phases was decreased and the volume fraction of the 2212 phases was dominant with increasing of $\mathrm{Fe}$ doping. These measurements indicate that $\mathrm{Fe}$ doping decreased the critical temperature and degrade the formation of high- $T_{c}$ phase of high temperature superconductor (HTS) compared with the undoped sample.

\section{Acknowledgement}

The authors would like to thank the Ministry of Higher Education (MOHE), Malaysia for the financial support via Research Acculturation Grant Scheme (RAGS) no. 600-RMI/RAGS 5/3 (7/2013).

\section{References}

1. Maeda, H., Tanaka, Y., Fukutomi, M. and Asano T. (1988). A new high-Tc oxide superconductor without a rare earth element. Japanese Journal of Applied Physics, 27: 209-210.

2. Trong On, D., Sato, O., Fujishima, A. and Hashimoto, K. (1999). Change of the critical temperature of high-Tc single (2223) phase $\mathrm{Bi}-\mathrm{Pb}-\mathrm{Sr}-\mathrm{Ca}-\mathrm{Cu}-\mathrm{O}$ supercondcutors by intercalation process. Journal of Physics and Chemistry of Solids, 60: 883-890.

3. Mulay, V. N., Siva Prasad, P. V. L. N., Bhupal Reddy, K. and Jaleel M. A. (1990). Studies on the synthesis of $\mathrm{Bi}_{2} \mathrm{CaSr}_{2} \mathrm{Cu}_{2} \mathrm{O}_{\delta}$ by different chemical routes. Journal of Materials Science Letter, 9: 1284-1287.

4. Halim, S. A., Mohamed, S. B., Azhan, H., Khawaldeh, S. A. and Sidek, H. A. A. (1999). Effect of barium doping in Bi-Pb-Sr-Ca-Cu-O ceramics supercondcutors. Physica C, 312: 78-84.

5. Terzioglu, C., Yilmazlar, M., Ozturk, O. and Yanmaz, E. (2005). Structural and physical properties of Smdoped $\mathrm{Bi}_{1.6} \mathrm{~Pb}_{0.4} \mathrm{Sr}_{2} \mathrm{Ca}_{2-\mathrm{x}} \mathrm{Sm}_{\mathrm{x}} \mathrm{Cu}_{3} \mathrm{O}_{\mathrm{y}}$ superonductors. Physica $C$, 423:119-126.

6. Suazlina, M. A., Yusainee, S. Y. S., Azhan, H., Abd-Shukor, R. and Mustaqim, R. M. (2014). The effects of nanoparticle addition in Bi-2212 superconductors. Jurnal Teknologi, 69(2): 49-52.

7. Gul, I. H., Anis-ur-Rehman, M. and Maqsood, A. (2006). Temperature dependence of thermal and electritrical conductivity of Bi-based high-Tc (2223) superconductor. Physica C, 450: 83-87.

8. Shalaby, M. S., Hashem, H. M., Hammad, T. R., Wahab, L. A., Marzouk, K. H. and Soltan, S. (2016). Higher critical current density achieved in Bi-2223 High- $\mathrm{T}_{\mathrm{c}}$ superconductors. Journal of Radiation Research and Applied Sciences, 9: 345-351.

9. Godeke, A., Abraimov, D. V., Arroyo, E., Barret, N., Bird, M. D., Francis, A., Jaroszynski, J., Kurtev, D. V. and Markiewicz, W. D. (2017). A feasibility study of high-strength Bi-2223 conductor for high-field solenoids. Superconductor Science and Technology, 30(3), 035011. 
Suazlina et al: THE EFFECTS OF FE-DOPING ON MECHANICAL PROPERTIES IN

$\mathrm{Bi}_{1.6} \mathrm{~Pb}_{0.4} \mathrm{Sr}_{2} \mathrm{Ca}_{2} \mathrm{Cu}_{3-X} \mathrm{Fe}_{X} \mathrm{O}_{Y}$ SUPERCONDUCTOR

10. Gul, I. H., Rehman, M. A., Ali, M. and Maqsood. A. (2005). Effect of vanadium and barium on the Bi-based (2223) superconductors. Physica C, 432: 71-80.

11. Sarun, P. M., Vinu, S., Shabna, R., Biju, A. and Syamaprasad, U. (2008). Highly enhanced superconducting properties of Eu-doped (Bi,Pb)-2212. Materials Letter, 62: 2725-2728.

12. Yilmazlar, M., Ozturk, O., Aydin, H., Akdogan, M. and Terzioglu, C. (2007). The effect of $\mathrm{Sm} \rightarrow \mathrm{Ca}$ substitution on mechanical properties of BSCCO superconductors. Chinese Journal of Physics, 45: 128-134.

13. Khalil, S. M. (2001). Enhancement of superconducting and mechanical properties in BSCCO with Pb additions. Journal of Physics and Chemistry of Solids, 62: 457-466.

14. Bruneel, E., Degrieck, J., Van Driessche, I., Hoste, S. (2002). Mechanical properties of Bi-2223/Ag bulk composites. Physica C, 1063: 372-376.

15. Ling, H. C. and Yan, M. F. (1988). Microhardness measurements on dopant modified superconducting $\mathrm{YBa}_{2} \mathrm{Cu}_{3} \mathrm{O}_{7}$ ceramics. Journal of Applied Physics, 64: 1307-1311. 